\title{
DỨcin
}

Technological University Dublin ARROW@TU Dublin

2004-01-01

\section{Colonialism and Journalism in Ireland}

\author{
Michael Foley \\ Technological University Dublin, michael.foley@tudublin.ie
}

Follow this and additional works at: https://arrow.tudublin.ie/aaschmedart

Part of the Communication Commons

\section{Recommended Citation}

MICHAEL FOLEY. Colonialism and Journalism in Ireland, Journalism Studies, Volume 5, Number 3, 2004. doi:10.1080/1461670042000246115

This Article is brought to you for free and open access by the School of Media at ARROW@TU Dublin. It has been accepted for inclusion in Articles by an authorized administrator of ARROW@TU Dublin. For more information, please contact arrow.admin@tudublin.ie, aisling.coyne@tudublin.ie,gerard.connolly@tudublin.ie.

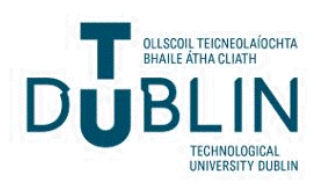


Antenna \& High Frequency Research Centre

\section{Articles}

Dublin Institute of Technology

Year 2004

\section{Colonialism and Journalism in Ireland}

Michael Foley

Dublin Institute of Technology, michael.foley@dit.ie

This paper is posted at ARROW@DIT.

http://arrow.dit.ie/ahfrcart/1 


\section{— Use Licence}

\section{Attribution-NonCommercial-ShareAlike 1.0}

You are free:

- to copy, distribute, display, and perform the work

- to make derivative works

Under the following conditions:

- Attribution.

You must give the original author credit.

- Non-Commercial.

You may not use this work for commercial purposes.

- Share Alike.

If you alter, transform, or build upon this work, you may distribute the resulting work only under a license identical to this one.

For any reuse or distribution, you must make clear to others the license terms of this work. Any of these conditions can be waived if you get permission from the author.

Your fair use and other rights are in no way affected by the above.

This work is licensed under the Creative Commons Attribution-NonCommercialShareAlike License. To view a copy of this license, visit:

- URL (human-readable summary):

http://creativecommons.org/licenses/by-nc-sa/1.0/

- URL (legal code):

http://creativecommons.org/worldwide/uk/translated-license 


\title{
Colonialism and Journalism in Ireland
}

\author{
MICHAEL FOLEY Dublin Institute of Technology, Ireland
}

\begin{abstract}
Irish journalism developed during the 19th century at a time of tremendous change. While journalists were involved in the debates about nationalism, both as commentators and in many cases activists, they also developed a journalism practice that corresponded to the professional norms of journalists in Britain and the United States. It would appear that the middle-class nature of Irish journalists meant there was a dual pressure towards professionalising journalism and fighting for legislative independence. Both factors came together in the development of a public sphere, where professional journalists were involved in creating public opinion.
\end{abstract}

\section{Key Words: Journalism, Ireland, Professionalism, History, Colonialism, Newspapers}

Since the collapse of the Communist regimes in Eastern Europe, there has been renewed interest in the role of the media in transitional societies. Mark Thompson's work (1999) on the media in former Yugoslavia, and its role in fomenting war, was an important text in that it offered a unique analysis of the negative role of the media in societies ruled by totalitarian governments. Such an analysis could have been applied to the role of Rwanda radio station, Radio MilleColline, which broadcast material designed to incite genocide, or to any number of countries where the media were tied to Governments and became an instrument of government policy. Even the bombing of the television building in Belgrade by NATO forces received a mixed reaction, with some denouncing the action as an attack on the media, while others suggested that as the media in Serbia were merely tools of the Government, the television station was a legitimate target.

From Russia to Palestine, journalists are being asked to shake off the work practices and habits of a lifetime, and take on a new role within democratic structures, even where those structures themselves are at best in the embryonic stage. Within the Soviet world those practices included

...a professional ethos centred around the import-
ance of (standardized) style and presentation. Po- litically loyal journalists saw themselves as aides to the authorities, acting as propagandists and organisers; more critical journalists, for whom investigative reporting was not a real possibility, developed the skill of writing in such a way as to enable their audience to read between the lines. (Davis et al., 1998)

International organisations, such as the International Research and Exchange (IREX), the European Union, as well as a host of nongovernmental organisations (NGOs) have been funding journalist training. Major media organisations such as the $\mathrm{BBC}$ and Reuters have also been involved in media training initiatives. Much of the effort has gone into trying to inculcate professionalism, usually as defined by Western norms. However, there is little doubt that whatever norms are used as a model, those of the United States, Britain or continental Europe, many journalists have problems finding their place within democratic structures. In Eastern and Central Europe, the Middle East and other parts of the world, journalists and editors have found it difficult to report with any degree of impartiality or fairness. They are being asked to take on the mantle of objectivity in a post-modern world that denies that objectivity is possible, or even valuable. Many journalists remain close to political organisations or ideologies, and often display a remarkable lack of professional solidarity or identification (Foley, 1995, p. 18; 1999, pp. 180-6; 2002, p. 214). 
Although nearly a century separates the events surrounding Irish independence and the collapse of Communism in Eastern and Southeastern Europe, it is still worth asking why the press in Ireland in the late 19th and early 20th centuries did not display the problems evident in today's transitional political cultures as Ireland moved from a colonised country, through the struggle for independence to independence itself, and how it developed a media operating more or less in step with professional norms. This paper explores Irish journalism during the colonial period in order to see what it was in Irish history that led to Ireland's peculiar development within the post-colonial world.

\section{Irish Journalism}

Ireland achieved independence in $1922,{ }^{1}$ following a century or more of political and social struggles and, finally, a bitter war of independence. Irish journalists, who were often themselves engaged in those same struggles, had developed professionalism within the context of a political and strongly partisan press. There were a number of reasons for this. Ireland was politically a part of Great Britain through the Act of Union of 1800, and had been influenced by the debates about freedom of expression and liberty of the press that had been part of intellectual discourse since Milton. Despite the intellectual debate that has been taking place since the 17th century, the British authorities continued to be reluctant to entertain the notion of a free press within England, Scotland and Wales, and the situation was far worse in Ireland. For nationalists, freedom of thought and opinion were ideas that were part of the intellectual inheritance of the French Revolution and its republican ideology, which had inspired the United Irishmen in 1798 and would continue to be part of republican thinking into the 20th century. That was the intellectual context within which journalism developed in Ireland, a development that had a profound effect on the way politics evolved and shaped and fashioned the nature of the independence that was finally achieved.

Journalism, as distinct from newspapers, developed in both Ireland and Britain during the 19th century and is, to use Jean Chalaby's term, an "invention" of the Victorian era (Chalaby, 1998 , p. 3). Superficially, there are many similarities between the journalistic cultures of the two islands: Irish journalism grew up when Ireland was part of the Union of Great Britain and Ireland. The similarities are all the more evident when one recalls the many highly influential Irish journalists, such as William Howard Russell, ${ }^{2}$ James J. O'Kelly and T. P. $\mathrm{O}^{\prime}$ Connor, who worked in Britain. Irish journalism was, however, influenced by much more than the journalism of London. Historically, not only had Irish journalists worked all over the world, especially in North America and Australia, but many worked as foreign correspondents in far-flung corners of the Empire for British newspapers. All these contacts, locational and ideological, inevitably influenced how journalism developed as a professional practice.

If journalism is a 19th-century construct, its emergence in Ireland was at a time of fundamental change. The century opened with the Act of Union; which was followed by a series of major, often dramatic political and economic developments; Catholic Emancipation; ${ }^{3}$ the Repeal Movement; ${ }^{4}$ the Famine of the 1840s; the Land War; the rise of both militant and constitutional nationalism; the political debates surrounding Home Rule, the struggles of the Irish Party at Westminster and the rise and fall of Parnell; 5 the War of Independence; and, in 1922, Irish independence itself. Journalists in Ireland worked as professional recorders of these events, on the English and American journalistic model, while also retaining a politicised press and a tradition of political engagement into the 20th century, not unlike journalism in Europe. Such journalists working in Ireland operated within a colonial society-one going through massive social, political, economic, religious and cultural transformation. Irish journalism, therefore, came of age during a time of far-reaching change, against a background of ever-increasing political agitation, and alternately recurring threat and reality of famine. It was precisely these events that hindered the development of the commercial press, of the type whose development in Britain from the 
1850s onwards is so well analysed by James Curran and Jean Seaton (1997) in their pioneering work on the British media, Power Without Responsibility. ${ }^{6}$ Colonial conditions and the state of Irish capitalism delayed many of the economic developments within the media that took place in Britain.

There were also other factors at play: The national system of education; the abolition of stamp duty; accelerating efficiency in conjunction with decreasing costs of resources, tools and processes; improved transport for distribution; intensification of population concentrations through urbanisation; improving telegraphy and increasing advertising revenue were the major factors in what Raymond Williams (1971) called the "Long Revolution" of which the remarkable growth of a cheap press in the second half of the 19th-century was a major component.

In Ireland even the most humble journalists reported on historic events, often at some danger to themselves. Journalist Andrew Dunlop recounts how he came to the aid of Charles Stewart Parnell when the redoubtable leader of the Irish Parliamentary Party came under direct physical attack.

In one of these attempts a man got hold of him [Parnell] by the legs and the Irish leader was in great danger of being pulled through one of the open spaces of the wooden railing of the platform, which alone separated him from the angry crowd. I was standing close by him throughout the entire scene and was thereby enabled to frustrate the attempts by taking my umbrella and bringing the knobbly end of the handle heavily down on the knuckles of Mr Parnell's assailant. (Dunlop, 1911, p. 153)

Dunlop, whose memoir of his time in Irish journalism from the 1860s to the early years of the 20th century will be discussed again as a rare and invaluable source of journalistic practice in the second half of the 19th century, goes on to tell us that "shortly after the incident at Sligo already related, another occurred in the same town, in which I narrowly escaped being mobbed" (1911, p. 159). And elsewhere, he gives an account of covering an eviction and the risk of being mistaken for a pernicious process server who delivered the eviction notice. According to Dunlop:

It was the practice at the time to bring down special bailiffs from Dublin, men who were not known in the locality, so that the identity of the process server might be more difficult to ascertain. One result of this, however, was that any civilian who was a stranger ran a risk of being mistaken for a process server. (1911, p. 62).

The illustrated newspapers made much pictorial mileage out of such occurrences. The Illustrated London News, for instance, thought it worth recording the treatment of one of its special artists in Ireland. An illustration showing the unfortunate artist being drummed out of an Irish town by a crowd brandishing sticks, who had probably mistaken him for a process server, was published towards the end of the Land War. The dangerous situation was uncharacteristically understated in its caption, entitled "Our Special Correspondent Misunderstood by the Crowd" (Illustrated London News, 25 December 1886, p. 693).

Increasing sectarianism in Northern Ireland, especially in Belfast, offered further differences between the working experiences of Irish journalists compared to their British colleagues. For Irish journalists covering political events, sectarian violence and riots were part of the job. The reaction of a visiting journalist from England, F. Frankfort Moore, is interesting in that he was evidently shocked at the experiences of his Irish colleagues. Moore was so taken aback at the risk of working as a reporter in Belfast in the 1880s that he suggested they be paid danger money. As he put it himself:

I chanced to be in Belfast at the time of the riots in 1886, and in my experience of the incidents of every day and every night led me to believe that British troops have been engaged in some campaigns that were a good deal less risky to the war correspondents than the riots were to the local newspaper reporters. Six of them were more or less severely wounded in the course of a week. I am strongly of the opinion that the reporters should have been paid at the ration of war correspondents at that time. (Moore, 1895, p. 220)

There were other differences between the journalism of England and Ireland. In his memoir of his time as a journalist, later a barrister, 
and then a member of parliament (MP), Mathias Bodkin notes: “in England Press work is specialised, the Irish reporter is a jack of all trades" (Bodkin, 1914, p. 28).

According to Kevin B. Nowlan, it was the editor of the pro-emancipation newspaper, the Morning Register, Michael Staunton, who first employed reporters "on the London model" in 1824, a practice that was followed by other newspapers (Nowlan, 1984, p. 15). Staunton's decision to employ reporters meant the practice of culling foreign news from the London newspapers, at no cost, declined and in its stead came local news, written by these local new reporters. The hiring of reporters could not have been better timed, coinciding as it did with the first mass political campaign in Ireland, the campaign for Catholic Emancipation.

\section{Catholic Emancipation, Repeal and the Creation of a Public Sphere}

The journalist inscribing his notebook with a shorthand note at a public meeting was, in effect, facilitating the development of a public sphere within which political debates took place. From the end of the 18th, right up into the 20th century, campaigns for political and social change were often linked with newspapers and other forms of journalism. Additionally, the protagonists were themselves, variously, political activists, Members of Parliament or members of revolutionary organisations. As Joep Leerssen explains:

Printing was revolutionised by the invention of the rotary press in 1811; paper manufacture likewise by the invention of mechanised paper production in the 1790s and the introduction of wood pulp as an ingredient. As a result the production costs of printed matter plummeted in the decades following 1810 - that is to say, precisely at the time when Catholic emancipation redefined the accessibility and distribution of Ireland's public space and public sphere. (Leerssen, 2002, pp. 37-8)

Emancipation was Daniel O'Connell's first great agitation. The winning of Catholic Emancipation in 1829 was a constitutional revolution that was achieved by mobilising public opinion. The Catholic Association, established by Daniel O'Connell, was a mass movement funded by the so-called "Catholic Rent", the penny-amonth subscribed by thousands of people around the country. By the 1820s, the Catholic gentry (of which O'Connell was a representative), together with commercial interests in towns such as Waterford, had evolved a "liberal Catholic" politics; as Roy Foster explains, O'Connell's lieutenants, "prosperous farmers, businessmen, the urban merchant community and newspaper editors were much in evidence" (Foster, 1988, p. 299).

O'Connell's own understanding of the press's role is evident in his grasp of the part played by editors in campaigns for Catholic Emancipation and, later the Repeal Movement, which sought the repeal of the Act of Union. The extent to which O'Connell advocated the development of the press and used it to his political advantage is striking, The Cork Examiner, for example, founded in 1841, actively supported O'Connell. It was first published by John Francis Maguire, who was for many years an MP and himself supported $\mathrm{O}^{\prime}$ Connell in the House of Commons. The example of Maurice Lenihan is also instructive. He was born in 1815 in Waterford, the son of a prosperous draper and woollen merchant, the sort of middle-class Catholic who was the backbone of the Catholic Association. Lenihan was educated locally and entered journalism, covering the local assizes. He worked for a number of Munster newspapers, including the Cork Examiner, before being urged by Daniel O'Connell to start a newspaper in Nenagh, Co. Tipperary, advocating repeal. O'Connell himself announced the founding of the Tipperary Vindicator in 1844.

While it is clear that O'Connell's campaigns, and the mobilisation of public opinion, benefited from being reported, especially by a sympathetic press, his relationship with the press was, at times, fraught. Charles Gavan Duffy, later one of the founders of The Nation, was one of those reporters hired by the Morning Register. Duffy was accused by O'Connell of attributing a speech to him that $\mathrm{O}^{\prime}$ Connell claimed he never gave. Duffy insisted he was accurate and left the meeting, accompanied by other reporters present (Oran, 1983, p. 56). Later, O'Connell was reconciled with the Morning Register and, as he said in his autobiogra- 
phy, "ceased abusing reporters" (quoted in Oran, 1983, p. 57).

O'Connell's two great campaigns, Catholic Emancipation and Repeal of the Act of Union, both supported and encouraged newsrooms or reading rooms. These spread throughout Ireland, supported by the temperance movement, the Liberal Clubs and the Repeal Movement itself. According to Marie Louise Legg, the temperance movement was adopted as the model for the Repeal Movement that sought to sway potential supporters through reading and debate. In 1844, the Association established rules for their reading rooms that were designed to "afford a source of rational occupation for the leisure hours of the industrious classes, where they may be instigated to increased patriotism, temperance and virtue" (Legg, 1999, p. 59).

\section{The Press in 19th-century Ireland}

Many newspapers supported temperance and often stated on their prospectus that they were read in a number of reading rooms, also known as newsrooms. Thus the Repeal Movement's fortunes were inextricably tied up with the growing press; through its reading rooms, it formed an association with the press, especially the provincial press. It gained recruits, while reading rooms made the provincial press widely available.

It would be a mistake to view the development of the press in Ireland, and with it journalistic practice, however, as one forward move towards greater freedom and influence. The attitudes of British governments towards issues such as press freedom might have been changing slowly in Britain, but in Ireland the authorities were still highly reluctant to entertain any move toward press freedom and harassment, and repressive legislation was used against the press throughout the period under discussion.

By 1880, most newspapers, both Dublin dailies and the weekly provincial newspapers were clearly identified politically. About onethird of the provincial newspapers had declared themselves as nationalist. This brought with it both popularity in terms of readership, but there was a downside. Their association with movements such as the Repeal Movement and other reform movements, such as the Land League meant many fell foul of the authorities who were still willing to use coercive legislation to control the press, by closing newsrooms and newspapers, destroyed printing presses and arresting proprietors for printing what was claimed to be seditious material.

In Dublin, there was the moderately liberal Dublin Evening Post, the conservative Dublin Evening Mail and, from 1859, the liberal unionist Irish Times. The two most influential newspapers were, however, the two nationalist newspapers, The Nation and the Freeman's Journal.

The Nation was the paper of Young Ireland, a movement that resembled European romantic nationalist movements, such as Mazzini's Young Italy. The Nation achieved a readership possibly as high as 250,000 by 1843 . Due to its availability in reading rooms its actual circulation would, of course, have been considerably less. The Freeman's Journal, however, was the most influential nationalist newspaper up until the 1890s. Its support for Home Rule was such that by the 1890s it was almost considered the official organ of the Irish Parliamentary Party, with Home Rule and land reform the only issues considered to be of any importance editorially.

Bill Kissane argues in Explaining Irish Democracy that there developed in 19th-century Ireland a civil society which had profound implications for the development of Irish politics:

If civil society is a sphere in which democratic practices can develop, in which an autonomous public opinion can be formed, and in which people acquire the skills that make them effective citizens in a modern polity, then the development of Irish civil society should be regarded as a precondition of the emergence of Irish democracy between 1918 and 1922. (Kissane, 2002, p. 113)

Kissane does not include journalism or the media in his analysis, other than mentioning the Institute of Journalists as one of the organisations that began to regulate professional life in the second half of the 19th century, but there is little doubt that the press and journalists were involved in the development of his civil 
society, with newspapers reporting on activities of the many civic, community, professional, self-help, political and other organisations which he argues were the foundations of Irish civil society. It was also journalists who were in the forefront of creating an autonomous public opinion that was necessary for the development of democratic practice. It is that mix of civil organisations and an autonomous public opinion as well as a media that was often in opposition to a colonial or authoritarian regime that is missing in today's transitional societies.

A major factor in the growth of newspapers was, of course, the political situation itself. Political events and the role of newspapers in expressing popular viewpoints allowed some to flourish, but others, failing to read public opinion accurately or holding political viewpoints that had fallen out of favour, just disappeared. As John Horgan writes

\begin{abstract}
It was a journalistic landscape which had evolved dramatically in the second half of the nineteenth century, as the old network of small Protestant owned papers, situated for the most part in garrison towns was supplemented, challenged and in some cases obliterated by the growth of nationalist papers whose success was based partly on rising education and income levels among the Catholic population, and partly on developing forms of political self expression from the Land War in the 1880 s onwards. (Horgan, 2001, p. 6)
\end{abstract}

Irish newspapers and journalism evolved out of political debates and events. The Nation itself grew out of a split within the Repeal Movement. Other publications were or became associated with particular political organisations, such as the Freeman's Journal and the Irish Parliamentary party and Parnell. Unionist newspapers such as The Irish Times were also political. It was they who voiced the other viewpoint in Ireland, that of defence of the union and the link with Great Britain.

\section{Professional Journalists and Journalistic Practices}

So who were Irish journalists? According to British sources, such as the novelist Thackeray, they were loveable rogues, hard-drinking hacks, but dishonest and not to be trusted. In
Ireland the picture is somewhat different. What emerges from memoirs and other accounts is of journalists coming from the emerging urban middle classes, especially the Catholic middle classes. The census of 1861 showed that there were 131 Protestants who declared themselves proprietors, editors and reporters, and 107 Catholics. By the census of 1891 the number of Catholics who declared that they were authors, editors, journalists or reporters was 221, compared to 193 Protestants (see the Census of Ireland of 1861: Religion, Education and Occupation, Part IV and the Census of Ireland of 1891: General Report).

Journalism offered paid employment for young men whose background did not include a private income, and who could not necessarily attend the only university, Trinity College, Dublin, for religious reasons. ${ }^{7}$ They were often politically aware and so journalism was an ideal occupation for young men interested in parliamentary politics. As Legg (1999) notes: “Journalism was a respectable profession unconnected with the problems of land ownership and the governing powers" (p. 23).

Far from being the hacks of English prejudice, many Irish journalists were idealistic men who saw in journalism a respectable way of influencing events. Commenting on the role and place of the journalist in Irish society towards the end of the 19th and early 20th century, Declan Kiberd compares the distinction made in Britain between the journalist and the artist or literary writers. He suggests that the chasm between the two that exists in many cultures did not so exist in Ireland.

The major debates of the Irish revival were con-
ducted in the pages of the Daily Express and United
Irishman. Contributing journalists belonged to a
profession for which a university degree was not a
prerequisite, which accounts for the democratic
tone and suspicion of aristocracy in these ex-
changes. Many supported movements for "self-
help", whether in adult education or Abbey
Theatre, on principles first laid down by Jonathan
Swift. He had shown in his brilliant polemics that
it was quite possible to close the gap between
journalism and art. (Kiberd, 2000, p. 464)

Before applying to enter Trinity College, Dublin, Mathias Bodkin consulted the Catholic clergy as to the wisdom of this move: 
My mother had strong conscientious objections to the Protestant University and we agreed to refer the matter to the great Dominican, Fr Tom Burke. His verdict was conclusive. "No Catholic could enter Trinity College", he declared, "without danger of shipwreck of Faith and Morals". (Bodkin, 1914, p. 25)

Later Bodkin worked for the Freeman's Journal, while reading for the Bar, a route to a professional qualification popular among middle-class Catholics.

While learning law and eating dinners I contrived by the influence of Bishop Duggan to get a place as an unpaid probationer on the reporting staff of the Freeman's Journal. (1914, p. 26)

It would have been unusual for 19th-century Irish journalists to have had a sophisticated understanding of their own professionalism, without being influenced from outside. The 19th-century Irish journalists were predominantly middle class. As well as reporters they were also editors and often owner editors. While the motives for entering journalism may have differed, there was emerging throughout the century a discernible agreement as to what constituted professional behaviour and a degree of solidarity between journalists.

The Irish press remained a political press long after the English media had become a wholly commercial enterprise. Journalists themselves had, however, absorbed ideas that we can now see as an emerging professional identity, normally associated with those working for the popular commercial press, including impartiality, objectivity and having skills such as shorthand.

Accuracy was a major factor in the professionalisation of journalism. The use of criminal libel and defamation encouraged the use of shorthand to ensure accuracy. Shorthand became a hallmark of the Irish journalist. Andrew Dunlop was aware of the importance of shorthand even before applying for a post with the Wexford Constitution in 1862:

Before applying for the reportership on the Wexford Constitution I had, of course, taught myself-I never got a single lesson-to write shorthand, knowing that to be the "open sesame" to journalistic work. (Dunlop, 1911, p. 3)
In his novel, White Magic, Bodkin gives an account of a young man seeking a post in a fictitious Dublin newspaper, The Free Press, obviously a thinly disguised Freeman's Journal. It is clear from this account that for all his accomplishments, including attending one of Ireland's foremost boys' schools, the editor is seeking skill in shorthand:

"What can you do?" Said Grayle ${ }^{8}$ shortly, with an abrupt change of manner.

"Very little, I'm afraid", said Gerald shyly. He had not he faintest notion what he might be expected to do.

"He took first place at Clongowes", broke in Dr Burton. "He was their best all round boy at books and games, and the captain of the eleven."

Grayle smiled.

"Have you ever written anything?"

"English composition and English poetry."

"You won't find much poetry about this place, I'm afraid. You don't know anything about shorthand, of course?"

"A little."

"What do you mean by a little. Can you take a speaker down?"

"If he's not too fast."

"Well, we'll try. No time like the present. There's a pencil and a notebook there on the table. You've got a knife? All right. Point the pencil on both sides for fear of accidents. We'll start when you are ready." (Bodkin, 1897, p. 129)

There are numerous testaments to the necessity of shorthand; again Bodkin, but now talking of his own entry to journalism, in his memoir:

For success in the profession of the Press the aspirant will need quickness, tact, literary aptitude and a smattering of universal knowledge. But these cannot be tested at the door. If a man can write even a hundred words a minute he is worth a try as a reporter. (Bodkin, 1914, pp. 27-8)

The legendary journalist and MP, T. P. O'Connor, ${ }^{9}$ who worked for Saunder's Newsletter in Dublin, the Telegraph in London and founded the Star, the Sun and T. P.'s Weekly, learnt shorthand in Galway, while attending Queen's College, Galway. In his biography of O'Connor, Henry Hamilton Fyfe gives an ac- 
count of the attractions of journalism for a boy of a particular class:

The expense (unavoidable at that time) of going to London to "eat his dinners"-that is to keep his terms at an Inn of Court-put an end to this dream of becoming a barrister. His hopes of a Civil Servant appointment were as effectively blasted. He looked around and saw that in Ireland then "there was always a good deal of what is called official note-taking-that is to say, the reporting of governmental commissions, of state trials and the like". The shorthand reporters who did this were paid at the rate of eight pence for every seventytwo words. During the latter part of his attendance at Queen's College O'Connor had been learning shorthand. (Fyfe, 1934, p. 25)

Following graduation O'Connor was employed as a reporter on Saunder's Newsletter, which he described as a "good old stout State and Church full-blown Protestant organ" at a salary of two pounds a week (Fyfe, 1934, p. 25).

At a time of passionate and sometimes violent political activity, many journalists consciously tried to forge a profession, engaging with issues of bias and objectivity, while being employed by a politically aligned press. Journalists often saw themselves as both politically aligned in their private lives, engaging with political controversy, while protesting their objectivity in what they produced professionally. Dunlop, for instance, while insisting on his impartiality in covering events associated with repealing the Union, was also the author of five pamphlets written for the Irish Loyal and Patriotic Union, the political association of Unionists businessmen, academics and landowners, founded in May 1885 to organise resistance to Home Rule (Dunlop, 1911, p. 121). In relation to one employment position, Dunlop declared that:

It was well known that my political views were not those of the conductors of the Freeman's Journal, but it was equally well known that whatever might be the views I entertained my employer could depend on my giving fair and impartial reports. (1911, p. 46)

And again, Dunlop recounts his experience on the Freeman's Journal and what was expected of him, as a reporter:

My experience on that journal [the Freeman's Jour- nal] at that period was, that its conductors desired that the members of the reporting staff should give unbiased reports. (1911, p. 46)

In fact the only complaint Dunlop has against any newspaper he worked for, at least professionally, is against a newspaper with which he would have been closely aligned politically. It was when working for The Irish Times that he complains about the sub-editors in a way instantly recognisable to any reporter today. His copy was changed, an act he clearly believes was contrary to correct professional behaviour. He was covering the murder of a land agent in the west of Ireland and saw, when he read his newspaper, that an addition had been made to his story. Clearly Dunlop viewed himself as a professional with his own reputation independent of the newspaper that employed him. Commenting on the incident he said:

This is a very unusual course for a sub-editor to adopt; for although as long as journalism is conducted on the anonymous system, the editor or it may be the proprietor of the newspaper is the person responsible to the public for what appears in its columns, the writer being responsible only to his employer; yet when a representative of a newspaper is sent on a mission such as I was entrusted with on this occasion, his identity necessarily becomes known, all the more so in my case because I was well known in Loughrea, and, to a limited circle-to those from whom he has been acquiring information for example-he is looked upon as the responsible individual. (1911, p. 180)

Dunlop, as a unionist, was not unique in working successfully for newspapers that hardly reflected his own politics. The veteran Fenian, ${ }^{10}$ John Devoy, himself a journalist in Chicago and New York, recounts in his memoir how editorial writers simply wrote to order and not necessarily from conviction. Writing about his fellow Fenian, William O'Donovan, who worked for The Irish Times, he said:

After his Spanish experience William O'Donovan returned to Dublin and became an editorial writer on The Irish Times. It is one of the anomalies of daily journalism in every country (including American), that the editorials are largely written by men who don't agree with the policy of the paper, but write to order. While William O'Donovan, a Fenian, was writing Tory editorials for The Irish Times, Jack Adams, Atheist, was doing the Catholic articles in the Freeman's Journal. O'Donovan and Adams used to meet at supper in 
the Ship Tavern in Abbey Street and have a good laugh over their articles, of which they didn't believe a word. (Devoy, 1969 [1929], p. 370)

Within the highly politically charged atmosphere of the Irish and, more especially, the Dublin press, however, neutral or unbiased reporting could always be questioned and journalists working as Dublin correspondents for London newspapers often found their work under scrutiny and comparison made with what they were writing for Irish newspapers. Dunlop was the cause of much controversy not simply for his reports for the Irish newspapers that paid his salary but also because of reports he was sending to England, especially for the Daily News. When Dunlop was the Irish correspondent for the Daily News it was anti-Home Rule, a position that changed from 1886. After five and a half years employed by the Freeman's Journal there was increasing pressure and "persistent effort of the nationalist party and nationalist journals to denounce all journalists who did not see eye to eye with themselves and especially those who had a connection with English newspapers" (Dunlop, 1911, p. 268). Finally, towards the end of 1884, "the nationalists began to press very strongly on the conductors of the Freeman's Journal that I ought not to be retained longer on its staff" (Dunlop, 1911, p. 250) According to Stephen Brown, writing of Dunlop in his survey of the Irish press in 1937, "the double role jeopardised his position on the Freeman. He was fiercely assailed in United Ireland ${ }^{11}$ and on public platforms. In 1885 he transferred to The Irish Times" (Brown, 1937, p. 164).

While political passions might sometimes test it, there is no doubt that by the 1870 s, at least, journalists and especially reporters had developed a sense of professional solidarity. It was probably forged on the road, sharing rail carriages, competing for telegraph connections and covering the same court cases. If the journalist covering events was viewed with suspicion in some quarters, as some of Dunlop's stories would indicate, this would also have an effect of forcing them together in a spirit of mutual defence.

Bodkin recounts an incident when covering the Royal Agricultural Show in Derry. The mayor of the city seemingly insulted the re- porters and so they acted together and refused to cover the events:

The word boycott was not known then, but the thing was. We reporters, in a body, politely declined all invitations to disputations, meetings or banquets, so the congratulatory address of the Corporation and the conciliatory response of his Excellency were lost to a curious public. Then the Viceregal influence was brought to bear on the newspaper proprietors, but they were loyal to their staff and declined to interfere". (Bodkin, 1914, p. 37)

Dunlop tells of another incident when it was thought likely that he might be asked to leave a dinner. Writing of his fellow reporters he said:

They at once volunteered the statement that should Dr Cardiff make any objection to my being allowed to remain during the dinner, they would leave the room also. This was but one of the many instances of the loyalty to each other which was almost always shown by Irish journalists. (Dunlop, 1911, p. 39)

\section{Journalism as a Profession}

By the end of the 19th century, Irish journalists were displaying a number of traits that would indicate a growing professional consciousness. They had a skill (shorthand), a professional adherence to objectivity and were aware of new developments within journalism, such as the new form of writing, the interview, a form that became popular at the end of the 19th century.

My idea of what an interview should be, if the matter is one of a controversial nature, is that the interviewer should place himself in antagonism to the interviewed, so that the points in controversy may be clearly brought out, and fully discussed. Only in this way can the truth be elicited, and the merits or demerits of each side exhibited. (Dunlop, 1911 , p. 233)

Given the developments outlined, it is hardly surprising that Irish journalists were keen to organise themselves as a profession. The National Association of Journalists, ${ }^{12}$ later renamed the Institute of Journalists, founded in London in 1892, had an Irish president by 1894 5, Thomas Crosbie, the editor and proprietor of the Cork Examiner. According to the Institute's "Grey Book", which contained membership lists, and rules, it had three official districts in 
Ireland, Dublin, Ireland (for journalists working outside Dublin and Ulster) and Ulster. Munster later became a sub-district. All three were designated as districts in 1890, which indicates a high degree of enthusiasm for the new organisation right from its earliest days. The membership was wide, with the Grey Book listing members right across the country. Ulster might have preferred its own district, but the membership lists show that journalists were willing to organise in an avowedly professional body, with a Royal Charter, across political and religious divides. ${ }^{13}$

By the end of the 19th and into the early 20th century, Irish journalists had a clear view of themselves as a distinct category of workers. Whether this was professionalism in the sense that the founders of the National Association of Journalists would have liked, or something else, is a moot point. Irish journalists may have joined the Institute of Journalists in great numbers and exhibited solidarity with each other, but as long-time journalist J. B. Hall observed:

\begin{abstract}
It has often impressed itself on me during my elongated experience that reporters are apt at times to overlook the peculiarly and, indeed, exceptionally important and responsible position which they occupy, and have a tendency to put up with indignities which are possibly the result of this same want of self assertion. Too often they forget that as representatives of the Press they are entitled to be regarded as the most important arbiters of the situation in which their profession places them. (Hall, 1929, p. 164)
\end{abstract}

Dunlop, of course, hardly ever overlooked the importance of the journalist. Commenting on the working conditions of reporters at the annual conference of the Institute of Journalists in 1897, he complained that the strain of shorthand note taking was often exacerbated by poor working conditions, such as not being able to hear properly or not having something suitable to lean a notebook on; "those who have charge of public functions ought not, by imperfect arrangements, to impose upon such a useful class of public servants".

A recognisable workplace organisation had also emerged, with similar practices and even a jargon. Terms such as morning town and night town, which denoted particular shifts worked by journalists, were common and are still in use today. Bodkin, commenting on a typical day in the Freeman's Journal, which he says could be applied to any Dublin newspaper of the day: ${ }^{14}$

In the Freeman's Journal, as in every well-regulated Irish newspaper office, there is a chief reporter, whose duty it is to set tasks to the rest. He knows, in his own expressive phrase "what's on". He keeps a record of all public proceedings. He has an instinct for news. Each morning the reporters meet the Chief in the reporters' room, are duly "marked" in a Doomsday Book, for their respective tasks, and are dispatched through the city and country on their news gathering missions. Wherever there is anything interesting to be seen or heard the reporter is there, nothing escapes his all-pervading activity. He writes for a busy and curious public not a word too few, not a word too many, so that he who runs (for tram or train) may read and understand. (Bodkin, 1914, pp. 28-9)

By the 1890s and the first years of the 20th century, great changes were beginning to take place and factors such as the growing influence of republicanism, the Irish Republican Brotherhood and other physical force movements, with their clandestine press, and the damage done to the Irish Parliamentary Party by the Parnell split had implications for the Irish media.

The Freeman's Journal suffered from the split in the Irish Party at Westminster. It had, from the 1890s, become an instrument of party policy, but managed to limp along for another two decades until final absorbed by its rival, the Irish Independent in 1924.

The merging of a number of newspapers associated with the Irish Party or Parnell, including the United Ireland, resulted in the businessman, William Martin Murphy, buying the Irish Independent. The Irish Independent was re-launched by Murphy in 1905 . He had looked towards the popular journalism of Lord Northcliffe for his inspiration and sent his editor, $\mathrm{T}$. R. Harrington, to London to study the popular press. Murphy had his own political views and was not afraid to use his newspapers to express them, particularly as the employers' leader during the great labour dispute known as the Dublin Lockout of 1913. However, there is no doubt that his entry into the newspaper industry meant the slow end of the dominance of a political press in Ireland. 
As Ireland entered the 20th century, and with independence in 1922, there was The Irish Times representing the Protestant and still mainly unionist population and the Catholic middle class represented by the conservative nationalist Irish Independent, and its sister newspapers. A range of small, often clandestine newspapers served the more radical republican tradition. That tradition of radical nationalist political thinking would have to wait until Eamon deValera founded his political party, Fianna Fail, and entered the Irish Parliament (Dail Eireann) before it had a mainstream newspaper. ${ }^{15}$ In 1931 deValera founded the Irish Press, followed by the Evening Press and, in 1949, the Sunday Press. The three newspapers had a huge impact on Irish journalism. The group continued until 1995, when the group of newspapers collapsed.

From the mid-19th century, journalists in Ireland had forged a professionalism based on concepts of impartial reporting along with political engagement. In the case of Irish journalists, a belief in objectivity or impartiality and the professional skills to deliver it was often necessary to ensure employment in a small media market. It meant that journalists could move from newspaper to newspaper regardless of the editorial line or even the ownership or whatever their own political opinions. We have seen how Andrew Dunlop moved from nationalist to unionist newspapers and how Fenians felt comfortable working for unionist newspapers. Professionalism meant a journalist could work for a newspaper whose editorial position he did not agree with.

The number of journalists engaged in politics was substantial. At one time the Irish Nationalist Party in Westminster had more journalists within its elected ranks than any other political party, rising from a mere one in 1880 to 15 in 1895. But politically engaged journalists were also working outside Westminster. Leading nationalist activists, John Devoy, Joseph Clarke, Edmund O'Donovan, Arthur Griffith and Bulmer Hobson, were all journalists and editors. Patrick Pearse and James Connolly, the two leaders of the 1916 rising, were, at various times, journalists and editors. The link between journalism and politics continued for some time, with a number of journalists who became employed by the Irish Press especially, who were former members of the IRA (Irish Republican Army) and or Sinn Fein. However, within an independent Ireland the links between politics and journalism began to weaken at the same time as newspapers began to seek wider audiences. Outside Dublin, of course, with the disappearance of so many unionist newspapers, the need to hold a partisan editorial viewpoint became irrelevant.

\section{Conclusion}

As Ireland shifted from a colonial to a post-colonial society, the growing professionalisation of journalists, with their sense of solidarity, a common ideology in objective reporting, along with a professional confidence as displayed in various journalistic memoirs, meant they were well placed to make the transition from being a politically engaged group of workers to a professional group working for a post-colonial, less politically aligned press.

Irish journalists were influenced by debates about freedom of expression and the press and democracy that had been part of British and European discourse and adapting them to Ireland's colonial situation. If Britain was reluctant to extend a tolerance of the press to Ireland, the Act of Union made it difficult to apply a double standard with any consistency. This allowed journalists to work within and contribute to an embryonic public sphere and a growing civil society, which led to a democratic culture that was influenced by an increased civic involvement in Britain, the Continent and in Ireland itself. Throughout the 19th century, journalists were being pulled in a number of directions: firstly, they sought to make journalism a respectable profession for the offspring of the rising Catholic middle class who were often precluded from other professions, a situation no doubt helped by the fact that journalism developed in the English language rather than in Irish; secondly, journalism was also a place where the politically engaged could find employment.

Journalists in transitional societies have to learn democratic practices and understand the role of media in democracy, whereas in late 
19th-century Ireland, the politically engagedjournalist was a common phenomenon and had a developed sense of the media role. Nationalist Members of Parliament often continued to work as prominent journalists, using their journalism to fund political careers in the era before MPs were paid a salary. Journalists had also adopted more radical positions, from the Young Irelanders working for The Nation, to the revolutionary Fenians having few problems earning a living working even for unionist newspapers.

The size of the Irish media, its role as a creator of public opinion and the need to develop a labour market meant the journalist, however politically engaged, used such concepts as objectivity and impartiality as a protection against being the victim of political and editorial change and as a means of selling his labour to as wide a market as possible. It could also be argued that to adopt objectivity was itself a radical position in a colonial context, in that it set journalists in opposition to a state whose actions, whether in legislation or within institutions such as the courts of law, would rarely be viewed as legitimate. The act of being "objective" might itself be viewed as being partisan, in that it allowed the nationalist press to remain adversarial by simply not legitimising the colonial state.

Following Irish independence, the political role of the journalist shifted. His or her role now became one of nation building and giving credibility to the new state. Even the pro-unionist Irish Times adopted the official names of the institutions of the new state, such as Taoiseach, for prime minister and the Dail, for parliament. In a similar vein, the newspaper founded by deValera, the Irish Press, in 1931 to give support to his new constitutional political party, Fianna Fail, was forced to plough a delicate furrow between partisanship and professional norms, well aware that to fall too far on either side would threaten the credibility of the new venture. In short, the professionalised journalist was now well placed to play a legitimising function within a post-colonial Ireland.

\section{Acknowledgement}

I would like to thank Professor John Horgan of Dublin City University, Dr Muiris MacChonghail, Dublin Institute of Technology and Dr Niamh O'Sullivan of the National College of Art and Design for their help and advice in writing and researching this paper.

\section{Notes}

1 Irish independence was achieved in 1922 when the Irish Free State was established. Until 1948, when a republic was declared, Ireland had Dominion status within the British Commonwealth on the same basis as Canada.

2 William Howard Russell, the "father of war correspondents", worked for the London Times and famously covered the Crimea War for that newspaper. He was born in Tallaght, Co. Dublin and educated at Trinity College.

3 Catholic Emancipation was achieved in 1829 and so allowed Catholics to take seats in the Westminster Parliament without subscribing to the Oath of Supremacy. It also opened up a range of other public offices to Catholics.

4 The Repeal Movement sought the removal of the Act of Union between Great Britain and Ireland, which had meant the abolition of the Irish Parliament, and the granting of Home Rule.

5 Charles Stewart Parnell (1846-91), MP and leader of the Irish Party at Westminster and one of the most important figures in Irish nationalism in the 19th century. He led two great campaigns, Home Rule and for land reform. He understood the importance of the media and founded the United Ireland and was closely associated with newspapers around the country. The Parnell split, caused when a fellow MP, Captain O'Shea, sued for divorce, citing Parnell who had been having an affair with Mrs O'Shea for some years. The split had a profound effect on Irish politics as well as the media. Those who continued to support Parnell after the split realised it was hopeless when Parnell lost the support of the Freeman's Journal.

6 Curran and Seaton argue that far from the traditional Whig view of press history, a political press and the repression that went with it gave way to an increasingly commercial press funded by advertising. In the end it was this, they argue, that was far more effective in ridding Britain of its radical political press than censorship and repression.

7 The provision of university education was a highly controversial issue throughout the late 19th century. In 1845 Parliament passed the Colleges Act, which established the Queen's Colleges in Belfast, Cork and Galway. They were condemned as "Godless" by the Catholic hierarchy. Later a Catholic college was founded in Dublin, by Papal authority, but it could not confer degrees. In 1908 the National University was established with colleges in Dublin, Galway and Cork.

8 The real editor of the Freeman's Journal was Sir John Gray. Bodkin worked as a journalist for the Journal. In his novel the fictitious newspaper is called The Free Press, the editor is John Grayle. Bodkin's memoir of his life as a journalist will be cited elsewhere.

9 T. P. O'Connor was the only member of the Irish Nationalist Party to sit at Westminster for an English Constituency. As well as working as a journalist and editor all his life he was one of the founders of the so-called New Journalism, see "The New Journalism", The New Review, October 1889, pp. 423-34. 
10 Fenians, a militant nationalist movement founded in New York by John O'Mahony in 1858. It was linked to the Irish Republican Brotherhood (IRB), a militant, secret organisation in Ireland.

11 United Ireland was founded by Charles Stewart Parnell in 1881 and edited by William O'Brien. It became the official newspaper of both the Land League and the Irish Parliamentary Party. It ceased publication in January 1898.

12 The Institute was previously the National Association of Journalists, which was founded in 1889.

13 The National Union of Journalists (NUJ) was founded in 1907 and Irish delegates were recorded as attending the Annual Conference in 1910 (Bundock, 1957, p. 26). By 1926 branches were formed in Dublin and Belfast and by the 1930s Irish Journalists had become enthusiastic members, with the new Irish Press being almost entirely a fully NUJ newspaper office at its foundation in 1931 (Bundock, 1957, pp. 110, 121). It might be interesting to speculate that the reason for this move towards trade unionism in Irish journalism was linked to the move towards a wholly commercial press.

14 What is remarkable is that such names are still used in Dublin newsrooms today.

15 DeValera and his followers had refused to recognise the Irish Free State that was established by the Treaty of 1922 because of the partition of the country. However, following the civil war he founded Fianna Fail and the Irish Press newspaper and entered parliament. See O'Brien (2001) for a fuller treatment of the Irish Press and its relationship to Fianna Fail.

\section{References}

Bodkin, Mathias M'Donnell (1897) White Magic, London: Chapman Hall.

Bodkin, Mathias M'Donnell (1914) Recollections of an Irish Judge, Press, Bar and Parliament, London: Hurst and Blackett.

Brown, Stephen (1937) The Press in Ireland: a survey and guide, Dublin: Browne and Nolan.

Bundock, Clement (1957) The National Union of Journalists: a jubilee history 1907-1957, Oxford: Oxford University Press.

Chalaby, Jean K. (1998) The Invention of Journalism, London: Macmillan.

Comerford, R. V. (1998) The Fenians in Context: Irish politics and society 1848-82, Dublin: Wolfhound Press.

Curran, James and Seaton, Jean (1997) Power Without Responsibility: the press and broadcasting in Britain, London: Routledge.

Davis, Howard, Hammond, Philip, Nizamova, Lilia (1998) "Changing Identities and Practices in Post-Soviet Journalism",

European Journal of Communications 13(1).

Devoy, John (1969 [1929]) Recollections of an Irish Rebel, Shannon: Irish University Press.

Dunlop, Andrew (1911) Fifty Years of Irish Journalism, Dublin: Hanna \& Neale.

Foley, Michael (1995) "Democracy Courtesy of Thomas Cook", Index on Censorship 26, p. 18.

Foley, Michael (1999) "A Tale of Three Cities", Index on Censorship 28, pp. 180-6.

Foley, Michael (2002) "The Vardar Shores of Peace", Index on Censorship 31, p. 214

Foley, Michael (2003) "Northern Ireland Journalists", in: Peter McIntyre (Ed.), Live News: a survival guide for journalists, Brussels: International Federation of Journalists.

Foster, Roy (1988) Modern Ireland 1600-1972, London: Allen Lane.

Fyfe, Hamilton (1934) T. P. O'Connor, London: George Allen \& Unwin.

Hall, J. B. (1929) Random Records of a Reporter, Dublin: Fodhla Press.

Horgan, John (2001) Irish Media: a critical history since 1922, London: Routledge.

Kiberd, Declan (2000) Irish Classics, London: Granta.

Kissane, Bill (2002) Explaining Irish Democracy, Dublin: University College Dublin Press.

Larkin, Felix (2002) Paper presented to the Colloquium on Irish Press and Empire, NUI Galway, 16 March.

Leerssen, Joep (2002) Hidden Ireland, Public Sphere, Dublin: Arlen House.

Legg, Marie-Louise (1999) Newspapers and Nationalism: the Irish provincial press, 1850-1892, Dublin: Four Courts Press.

MacDonagh, Michael (nd) The Reporters Gallery, London: Hodder and Stoughton.

Moore, F. Frankfort (1895) A Journalist's Notebook, London: Hutchinson \& Co.

Nowlan, Kevin B. (1984) "The Origins of the Press in Ireland", in: Brian Farrell (Ed.), Communications and Community in Ireland, Cork: Mercier Press.

O'Brien, Mark (2001) DeValera, Fianna Fail and the Irish Press, Dublin: Irish Academic Press.

Oran, Hugh (1983) The Newspaper Book, Dublin: MO Books.

Thompson, Mark (1999) Forging War: the media in Serbia, Croatia, Bosnia and Hercegovina, Luton: Article 19.

Williams, Raymond (1971) The Long Revolution, London: Harmondsworth. 


\section{Author Query Sheet}

\begin{tabular}{|l|l|}
\hline \multicolumn{2}{|c|}{ Manuscript Information } \\
\hline $\begin{array}{l}\text { Journal } \\
\text { Acronym }\end{array}$ & rJOS \\
\hline $\begin{array}{l}\text { Volume and } \\
\text { issue }\end{array}$ & $5: 3$ \\
\hline Author name & Foley \\
\hline $\begin{array}{l}\text { Manuscript } \\
\text { No. (if } \\
\text { applicable) }\end{array}$ & \\
\hline
\end{tabular}

AUTHOR: The following queries have arisen during the editing of your manuscript. Please answer the queries by marking necessary corrections at the appropriate positions on the PROOFS. Do not answer the queries on the query sheet itself. Please also return a copy of the query sheet with your corrected proofs.

\begin{tabular}{|l|l|}
\hline QUERY NO. & \multicolumn{1}{c|}{ QUERY DETAILS } \\
\hline 1 & Foley, 1996 changed to 1995 (as Ref. list) - OK? \\
2 & Leerson, 2002 changed to Leersen (as Ref. list) - OK? \\
4 & Note 16 gave the IRA in full (now in the text) - should there have been a Note 16 about Sinn Fein? \\
5 & Comerford, 1998: please cite in text or delete \\
6 & Davis et al., 1998: please supply page range for article \\
7 & Foley, 2003: please cite in text or delete \\
& Larkin, 2002: please cite in text or delete. If citing, please supply title of paper \\
& \\
& \\
& \\
&
\end{tabular}

